\title{
STRATEGI KOMUNIKASI ANTARBUDAYA DOKTER KEPADA PASIEN DALAM PROSES PELAYANAN KESEHATAN DI RSU RAFFA MAJENANG
}

\author{
Grace Sinthike Kewas ${ }^{1}$; Rini Darmastuti ${ }^{2^{*}}$ \\ ${ }^{1,2}$ Fakultas Teknologi Informasi, Universitas Kristen Satya Wacana \\ Jl. Diponegoro 52-60, Salatiga 50711, Indonesia \\ *Penulis korespondensi; Email: ${ }^{1}$ gracesintikhe016@ gmail.com; ${ }^{2}$ rini.darmastuti@uksw.edu
}

\begin{abstract}
ABSTRAK
Majenang merupakan kota kecamatan di kota Cilacap yang terletak di ujung paling barat dan berbatasan dengan Jawa Barat. Letak geografis ini membuat budaya yang dimiliki masyarakat Majenang adalah percampuran antara budaya Jawa dan Sunda. Akibatnya, membawa dampak pada komunikasi antarbudaya yang terjadi, termasuk proses komunikasi dalam pelayanan kesehatan yang ada di RSU Raffa, Majenang. Penelitian ini bertujuan untuk mengetahui strategi apa yang digunakan oleh dokter kepada pasien yang berbeda budaya di Rumah Sakit Umum Raffa selama proses pelayanan kesehatan. Metode yang digunakan dalam penelitian ini adalah metode kualitatif dengan pendekatan etnografi. Hasil penelitian menemukan bahwa pertama, proses komunikasi antarbudaya yang dilakukan oleh dokter dan pasien terjadi dalam bentuk komunikasi verbal dan non verbal. Kedua, Hambatan yang terjadi dalam komunikasi antarbudaya ini adalah hambatan bahasa, persepsi dan budaya. Ketiga, strategi yang digunakan untuk mengatasi hambatan ini adalah dengan menggunakan penerjemah, edukasi pasien, mempelajari budaya dan karakter pasien dan sosialisasi ke desa-desa.
\end{abstract}

Kata kunci: Strategi komunikasi, komunikasi antarbudaya, Rumah Sakit Umum Raffa, Majenang.

\begin{abstract}
Majenang is a subdistrict city in the city of Cilacap which is located at the westernmost tip and is bordered by West Java. This geographical position makes the culture of the Majenang community a mix of Javanese and Sundanese culture. The involvement brought about intercultural communication that occurred, including the process of communication in the existing health services at Raffa General Hospital, Majenang. This study discusses what strategies are used by doctors for patients of different cultures at Raffa General Hospital during the health care process. The method used in this study is a qualitative method using ethnography. The results of the study found that first, the process of intercultural communication carried out by doctors and patients was carried out in the form of verbal and nonverbal communication. Second, the barriers that occur in intercultural communication are language, perception, and cultural barriers. Third, the strategies used to overcome these obstacles by using translators, patient education, cultural interaction and patient character and socialization to villages.
\end{abstract}

Keywords: Communication strategy, intercultural communication, Raffa General Hospital, Majenang.

\section{PENDAHULUAN}

Majenang merupakan salah satu kecamatan yang ada di Kabupaten Cilacap. Secara geografis, Majenang terletak di Cilacap bagian barat berbatasan langsung dengan Provinsi Jawa Barat, yang dibatasi oleh kecamatan Wanareja dan Dayeuh Luhur (Pemerintah Kabupaten Cilacap). Letak geografis yang berada di posisi Jawa Tengah paling barat dan berbatasan langsung dengan Jawa Barat, menjadikan banyaknya penduduk transmigrasi di Majenang, salah satunya penduduk suku Sunda. Transmigrasi ini juga membawa dampak pada penggunaan bahasa di masyarakat Majenang. Dalam kehidupan sehari-hari, penggunaan bahasa yang digunakan oleh masyarakat Majenang adalah bahasa Jawa Ngapak dan bahasa Sunda, dan berdasarkan penggunaan bahasa tersebut membuat mayoritas masyarakat Majenang terutama didaerah pegunungan tidak bisa berbahasa Indonesia.

Selain itu, Kejawen juga menjadi budaya yang menjadi ciri khas masyarakat Majenang. Kejawen adalah pandangan hidup orang Jawa yang melakukan kehidupan berdasarkan moralitas atau etika dan religi yang tercermin di dalam hubungan manusia dengan Tuhan, hubungan manusia dengan manusia lainnya, dan hubungan manusia dengan alam (Soesilo, 2004). Kepercayaan masyarakat Majenang terhadap Kejawen sudah terjadi secara turun temurun, sekalipun mereka sudah menganut agama tertentu.

Kepercayaan yang dianut ini yang kemudian membentuk cara berperilaku, berkomunikasi, pola pikir, persepsi, dan cara bergaul seperti yang diajarkan oleh 
budaya yang mereka hidupi. Melalui budaya dan bahasa yang dimiliki masyarakat Majenang tersebut, dapat dilihat bahwa tidak akan pernah ada komunikasi tanpa adanya budaya, dan tidak akan ada budaya tanpa komunikasi. Budaya yang mereka miliki sangat mempengaruhi komunikasi yang mereka lakukan, termasuk bahasa yang mereka gunakan. Sebaliknya, bahasa yang mereka gunakan dalam berkomunikasi, akan mempengaruhi budaya yang mereka miliki. Hal ini sesuai dengan pernyataan Edward T. Hall (dalam Liliweri, 2003:21) yang memberikan penjelasan bahwa antara budaya dan komunikasi dapat diibaratkan sebagai dua keping mata uang yang tidak dapat dipisahkan.

Komunikasi antarbudaya bisa terjadi dimana saja dan kapan saja. Komunikasi antarbudaya tidak hanya terjadi di antara orang-orang yang berbeda bangsa, ras, etnik, bahasa, dan agama. Namun, dapat juga terjadi di antara orang-orang yang berbeda tingkat pendidikan, status sosial, jenis kelamin, serta profesi. Salah satu profesi yang terlibat komunikasi antarbudaya itu adalah komunikasi antara dokter dan pasien.

Komunikasi antara dokter dan pasien yang terjadi di Rumah Sakit Umum Raffa Majenang ini dapat dikatakan sebagai komunikasi antar budaya, karena komunikasi ini dilakukan oleh peserta komunikasi yang memiliki latar belakang budaya yang berbeda. Dalam konteks ini, dokter-dokter di RSU Raffa Majenang ada yang berasal dari Jogja, Jakarta dan beberapa kota lainnya yang ada di sekitar Majeneng. Dokter-dokter ini memiliki budaya yang beraneka ragam. Ada yang berlatar belakang budaya Jawa, budaya Sunda dan budaya lainnya. Sementara itu pasien di RSU ini sebagian besar berasal dari Majenang dan memiliki latar belakang budaya Sunda. Perbedaan latar belakang budaya ini menjadi salah satu faktor yang mempengaruhi pada setiap peristiwa komunikasi yang dilakukan antara dokter dan pasien.

Selain latar belakang budaya, latar belakang Pendidikan juga menjadi faktor lainnya yang mempengaruhi setiap peristiwa komunikasi antara dokter dan pasien. Perbedaan latar belakang budaya dan latar belakang Pendidikan mempunyai peranan yang sangat penting pada saat proses simbolik dan proses transaksional terjadi dalam setiap peristiwa komunikasi yang terjadi antara dokter dan pasien. Pada tataran inilah terjadi komunikasi antar Budaya. Hal ini seperti yang dikatakan oleh Gudykunst dan Kim (1997 dalam Darmastuti, 2013: 63), bahwa komunikasi antar budaya merupakan proses transaksional dan proses simbolik yang melibatkan atribusi makna antara individu-individu dari budaya yang berbeda.

Komunikasi antarbudaya dapat dipahami sebagai suatu relasi atau hubungan antara individu-individu yang berlainan budaya, misalnya suku bangsa, etnik, ras, bahasa, dan sosial. (Regar, Kawung, \& Tangkudung, 2014). Komunikasi yang berlangsung pada dasarnya bersifat lisan, sehingga ide yang disampaikan lebih langsung dan nyata (lebih memiliki sense of communication). Dalam komunikasi, terdapat elemen penting yang menjadi faktor penunjang keberhasilan suatu komunikasi yaitu bahasa. Bahasa merupakan bagian integral dari budaya suatu masyarakat (Fauziah, 2015). Dalam kondisi tertentu, bahasa dapat memengaruhi dan membentuk perilaku dan sikap masyarakat, terutama dalam aspek pola pikir, persepsi, cara pandang, dan cara bergaul. Sistem kultural yang dimiliki oleh suatu masyarakat dicerminkan dalam bahasanya, sehingga menciptakan beragam bahasa yang menjadi ciri penanda tutumya. Keberagaman bahasa ini pada masanya nanti dapat memengaruhi komunikasinya, terutama komunikasi interpersonal (antarorang) yang berlatar budaya dan bahasa yang berlainan (Venus, A., Syafirah, N. A. Salam, 2019).

Charley H Dood (dalam Liliweri 2003: 19) mengatakan komunikasi antarbudaya meliputi komunikasi yang melibatkan peserta komunikasi yang mewakili pribadi, antarpribadi maupun kelompok. Komunikasi antar budaya yang terjadi antara dokter dan pasien di RSU Raffa, pada saat tertentu terjadi pada level antarpribadi, tetapi disaat yang lain

Di RSU Raffa Majenang, dokter merupakan tenaga medis yang mempunyai peranan penting dalam menyelesaikan permasalahan kesehatan seorang pasien. Komunikasi menjadi landasan penting dalam proses diagnosis, terapi maupun pencegahan penyakit. Komunikasi antar budaya menjadi urgensi dalam proses penyembuhan ini. Hanya saja hubungan yang terjadi antara dokter dengan pasien tidak selalu berjalan harmonis. Konflik dan kesalahpahaman atau miscommunication seringkali terjadi, yang disebabkan karena adanya perbedaan persepsi. Perbedaan persepsi ini seringkali muncul karena perbedaan latar belakang budaya dan perbedaan tingkat Pendidikan sehingga memunculkan pemahaman yang berbeda dalam komunikasi. Di sisi yang lain, bahasa yang digunakan dalam aktivitas sehari-hari menjadi salah satu faktor mengapa konflik dalam komunikasi antar budaya antara dokter dan pasien di RSU Raffa Majenang ini bisa terjadi. 
Dalam aktivitas sehari-hari di RSU Raffa Majenang, ketika mengobati pasiennya, dokter-dokter di RS ini selalu menggunakan bahasa Indonesia. Sedangkan pasien di RS ini kebanyakan menggunakan bahasa daerah, yaitu bahasa Sunda atau bahasa Jawa. Masih banyak masyarakat Majenang, terutama yang berasal dari gunung, yang belum paham bahasa Indonesia. Perbedaan bahasa inilah yang memunculkan permasalahan dalam komunikasi antar budaya antara dokter dan pasien di RSU Raffa. Mengacu dari pendapat Samovar dan Porter (1994), Three cultural elements have the potential to affect situations in which people from different backgrounds come together: (1) perception, (2) verbal processes, and (3) nonverbal processes". Menurut Samovar dan Porter, ada tiga elemen budaya yang dimiliki oleh suatu masyarakat dan memiliki potensi besar untuk mempengaruhi situasi ketika orang-orang yang berasal dari latar belakang budaya itu berkumpul. Ketiga elemen itu adalah persepsi, proses verbal dan proses non verbal. Tiga elemen ini juga yang mempengaruhi ketika peristiwa komunikasi antara dokter dan pasien di RSU Raffa terjadi.

Dalam konteks sebagai seorang komunikator dalam komunikasi antar budaya dengan pasien, dokter seringkali tidak memahami makna dari pesan yang disampaikan oleh pasien sebagai komunikan. Hal ini disebabkan karena perbedaan budaya serta bahasa yang digunakan pasien. Pada tataran ini, dokter belum mendapatkan tips yang jitu serta strategi yang tepat untuk berkomunikasi dengan pasien yang memiliki latar belakang budaya yang berbeda dengan pasiennya. Selama ini strategi yang digunakan oleh dokter adalah dengan menafsirkan dan memprediksi sikap dari pasiennya yang dapat pasiennya. Salah satu patokan yang digunakan adalah informasi terkait dengan usia dan pendidikan pasien, serta pasien tersebut berasal dari daerah mana.

Di sisi yang lain, pasien yang datang di RSU Majenang ini hampir sebagian besar adalah masyarakat di Majenang yang masih mempunyai kepercayaan terhadap Kejawen. Kepercayaan masyarakat Majenang terhadap budaya Kejawen membentuk tingkah laku, cara berkomunikasi dan juga pola pikir yang akhirnya berdampak pada proses pelayanan kesehatan di RSU Raffa seperti halnya dalam pemahaman medis. Banya dari masyarakat Majenang yang masih percaya bahwa penyakit yang mereka derita bukan disebabkan karena hal-hal medis, tetapi lebih dipengaruhi oleh hal-hal lain yang ada di sekitar kehidupannya. Terbatasnya informasi yang didapatkan masyarakat, membuat masyarakat terlalu cepat mengambil keputusan untuk melakukan pengobatan alternatif tanpa mengkonsultasikan kondisinya kepada dokter terlebih dahulu. Untuk mengobati penyakit mereka, mereka akan memilih berobat ke dukun dan sejenisnya, dibanding berobat ke dokter. Hal tersebut membuat penanganan medis terhadap kesehatan pasien akhirnya menjadi terhambat. Tidak jarang, pasien yang datang berobat ke RSU Raffa mengalami keterlambatan penanganan medis.

Dokter di RSU Raffa tidak begitu menghiraukan cerita rakyat yang berbau takhayul ataupun kepercayaan sebagian masyarakat Majenang dengan pengobatan-pengobatan tradisional. Padahal pendekatan personal kepada masyarakat dengan memahami budaya mereka dan memahami cerita rakyat serta kepercayaan yang mereka anut, bisa menjadi pendekatan yang efektif untuk kesembuhan pasien di RSU Raffa ini.

Pada tataran ini, perlu dipikirkan bagaimana strategi komunikasi atau cara berkomunikasi antara dokter dan pasien dengan berlandaskan pada pemahaman komunikasi antar budaya. Tujuannya adalah untuk membangun pemahaman yang sama antara dokter dan pasien pada saat berkomunikasi dan untuk mengurangi ketidakpastian ketika berkomunikasi. Berdasarkan latar belakang ini, maka yang menjadi pertanyaan adalah, "Bagaimana strategi komunikasi antar budaya dari dokter kepada pasien dalam proses pelayanan kesehatan di RSU Raffa Majenang ini”. Pertanyaan ini dapat dirumuskan dalam rumusan masalah:

1) Bagaimana komunikasi antarbudaya yang terjadi antara dokter dan pasien suku Jawa "Ngapak" di RSU Raffa Majenang?

2) Apa saja faktor penghambat dalam proses komunikasi tersebut?

3) Bagaimana strategi komunikasi yang digunakan dokter dalam melakukan proses pelayanan kesehatan kepada pasien Suku Jawa "Ngapak"?

Tulisan ini didasarkan pada hasil penelitian yang didasarkan pada hasil penelitian-penelitian terdahulu. Penulis menggunakan penelitian-penelitian terdahulu ini sebagai dasar untuk memahami komunikasi antar budaya dan untuk membangun wawasan penulis terkait dengan komunikasi antar budaya.

Beberapa penelitian terdahulu yang menjadi dasar pemahaman penulis dalam memahami komunikasi antar budaya ini adalah penelitian dengan judul "Strategi Komunikasi Antarbudaya Dalam Mengurangi Stereotipe Negatif Terhadap Suku Batak di 
Rusunawa Keudah, Banda Aceh". Penelitian yang dilakukan oleh Putri (Putri, 2014) ini bertujuan untuk mengetahui kendala yang dialami warga suku Batak dalam berkomunikasi di Rusunawa Keudah dan strategi komunikasi antarbudaya yang digunakan oleh warga bersuku Batak dalam mengurangi stereotipe negatif. Hasil dari penelitian ini adalah warga suku Batak di Rusunawa Keudah menggunakan strategi komunikasi akomodasi untuk mengurangi stereotipe negatif.

Penelitian kedua adalah penelitian Dorothy Simanjuntak (Simanjuntak, 2016) dengan judul "Pelayanan Kesehatan Dalam Pendekatan Komunikasi Antarbudaya (Studi Fenomologi Pelayanan Kesehatan Dokter Kepada Pasien Di RSUP H. Adam Malik Medan). Penelitian ini bertujuan untuk mengetahui proses pelayanan kesehatan dokter kepada pasien di Instalansi Rawat Jalan RSUP H. Adam Malik dalam pendekatan komunikasi antarbudaya. Hasil temuan penelitian ini adalah dokter yang sangat terbatas dalam memberikan penjelasan kepada pasien, minim informasi dan terkesan terburu-buru. Dalam peristiwa komunikasi antar budaya antara dokter dan pasien, bahasa, pengalaman, hambatan fisik, kompetisi dan hambatan nonverbal merupakan hambatan yang muncul dalam komunikasi antar budaya ini.

Penelitian yang ketiga adalah penelitian yang dilakukan Fitra Hadi (Hadi, 2017) dengan judul "Komunikasi Antarbudaya Pada Mahasiswa Bangka-Sunda (Studi Etnografi Komunikasi Kedwibahasaan Pada Mahasiswa Bangka-Sunda di FISIP UNPAS Bandung)". Tujuan dari penelitian ini adalah untuk mengetahui situasi komunikatif, peristiwa komunikatif, dan tindak komunikatif sehingga dapat mengetahui pola komunikasi mahasiswa Bangka-Sunda FISIP UNPAS. Hasil dari penelitian ini adalah proses komunikasi kedwibahasaan yang dilakukan oleh mahasiswa Bangka-Sunda di FISIP UNPAS Bandung melahirkan varietas bahasa yaitu, bahasa Bangka, bahasa Indonesia, dan bahasa Sunda tingkat sedang hingga kasar.

Tiga penelitian ini menjadi dasar pemahaman dan wawasan penulis dalam penulisan artikel ini. Sekalipun tulisan ini didasarkan pada tiga penelitian di atas, tetapi ada kebaharuan dari tulisan ini, yaitu pembahasan terkait dengan strategi komunikasi dalam komunikasi antar budaya yang dilakukan dalam dunia kesehatan dengan menggunakan pendekatan etnografi. Kebaharuan dari tulisan ini dalam kajian komunikasi kesehatan bukan hanya membahas tentang proses pelayanan dokter serta hambatannya seperti yang dilakukan oleh Simanjuntak, tetapi juga membahas tentang strategi komunikasi antar budaya di dunia medis.

Kebaharuan lainnnya, penelitian ini bukan hanya membahas tentang strategi komunikasi antar budaya terkait dengan stereotype negatif seperti yang dilakukan oleh Putri (2014), tetapi juga terkait dengan kepercayaan dan bahasa yang dimiliki oleh setiap partisipan komunikasi sebagai faktor penting dalam komunikasi antar budaya.

\section{TINJAUAN PUSTAKA}

\subsection{Identitas Budaya}

Secara etimologis, kata identitas berasal dari kata Identitty, yang berarti (1) kondisi atau kekayaan tentang sesuatu yang sama, suatu keadaan yang mirip satu sama lain; (2) kondisi atau fakta tentang sesuatu yang sana di antara dua orang atau dua benda; (3) kondisi atau fakta yang menggambarkan sesuatu yang sama diantara dua orang (individualitas) atau dua kelompok atau benda (Webster New World Dictionary dalam Darmastuti, 2013:94).

Menurut Ting-Toomey (dalam Darmastuti, 2013:94) identitas budaya atau kultural merupakan perasaan (emotional significance) dari seseorang untuk ikut memiliki (sense of belonging) berafiliasi dengan kultur tertentu. Masyarakat yang terbagi kedalam kelompok-kelompok itu kemudian melakukan identifikasi kultural (cultural identification, sebagai representasi dari sebuah budaya partikular). Identitas budaya yang terbentuk dalam kehidupan suatu masyarakat akan mempengaruhi persepsi diri setiap anggota dalam masyarakat. Bagaimana mereka memandang diri mereka, bagaimana mereka bersikap dan bertingkah laku, sangat dipengaruhi oleh identitas budaya mereka sendiri.

Identitas yang dimiliki oleh suatu masyarakat kalau tidak digunakan secara hati-hati, akan menjadi belenggu bahkan penjara bagi masyarakat tersebur. Hal ini seperti yang dikatakan oleh Murathan Mungan (dalam Samovar, Porter dan Daniel, 2012: 81),

Identity is a concept of our age that should be used very carefully. All types of identities, ethnic, national, religious, sexual or whatever else, can become your prison after a while. The identity that you stand up for can enslave you and close you to the rest of the world"

\subsection{Interaksionisme Simbolis}

Interaksionisme simbolis merupakan sebuah pergerakan dalam sosiologi yang berfokus pada cara-cara manusia membentuk makna dan susunan dalam 
masyarakat melalui percakapan. Barbara Ballis Lal meringkas dasar-dasar pemikiran gerakan ini sebagai berikut (Littlejohn, 2012:231):

1. Manusia membuat keputusan dan bertindak sesuai pemahaman subjektif mereka menemukan diri mereka

2. Kehidupan sosial terdiri dari proses-proses interaksi daripada susunan, sehingga terus berubah

3. Manusia memahami pengalaman mereka melalui makna-makna yang ditemukan dalam symbolsimbol dari kelompok utama mereka dan bahasa merupakan bagian penting dalam kehidupan sosial

4. Dunia terbentuk dari objek-objek sosial yang memiliki nama dan makna yang ditentukan secara sosial

5. Dunia terbentuk dari objek-objek sosial yang memiliki nama dan makna yang ditentukan secara social

6. Tindakan manusia didasarkan pada penafsiran mereka, dimana objek dan tindakan yang berhubungan dalam situasi yang dipertimbangkan dan diartikan

7. Diri seseorang merupakan sebuah objek yang signifikan dan layaknya semua objek sosial, dikenalkan melalui interaksi sosial dengan orang lain

Tiga konsep utama dalam teori yang dicetuskan oleh Mead ini ditulis dalam karyanya yang terkenal yaitu masyarakat, diri sendiri dan pikiran. Menurut pemahaman ini, dalam bentuknya yang mendasar, sebuah tindakan sosial melibatkan sebuah hubungan dari tiga bagian, yaitu gerakan tubuh awal dari salah satu individu, respon dari orang lain terhadap bagi gerakan tersebut dan sebuah hasil. Hasilnya adalah arti dari tindakan tersebut bagi pelaku komunikasi. Makna tidak semata-mata terletak dalam setiap hal ini, tetapi dalam hubungan ketiga hal tersebut.

Menurut Blumer, ada 3 prinsip utama yang terkandung dalam teori interaksionisme simbolik, yaitu Meaning (makna), language (bahasa) dan thought (pemikiran) (Griffin, 2003:56). Makna dalam interaksionisme simbolik, menurut Herbert Blumer (Soeprapto, 2002:120) dipahami dengan cara bertumpu pada 3 premis utama, yaitu:

1. Manusia bertindak terhadap sesuatu berdasarkan makna-makna yang ada pada sesuatu itu bagi mereka.

2. Makna itu diperoleh dari hasil interaksi sosial yang dilakukan dengan orang lain.

3. Makna-makna tersebut disempurnakan di saat proses interaksi sosial sedang berlangsung.

\subsection{Strategi Komunikasi}

Strategi komunikasi merupakan paduan dari perencanaan komunikasi (communication planning) dan manajemen (management communication) untuk mencapai suatu tujuan. Untuk mencapai tujuan tersebut strategi komunikasi harus dapat menunjukkan bagaimana oprasionalnya secara taktis harus dilakukan, dalam arti kata bahwa kepada situasi kondisi (Effendy, 2004:29). Seperti halnya dengan strategi komunikasi dalam bidang apapun, strategi komunikasi harus didukung oleh teori, karena merupakan pengetahuan berdasarkan pengalaman yang sudah diuji kebenarannya. Banyak teori komunikasi yang sudah diketengahkan oleh para ahli, tetapi untuk strategi komunikasi barangkali yang memadai baiknya untuk pendukung strategi komunikasi ialah apa yang dikemukakakn oleh Harold D. Lasswell. Menurut Laswell seperti yang dikutip dalam (Effendy, 2011:11) bahwa cara yang terbaik untuk menerangkan kegiatan komunikasi ialah menjawab pertanyaan "Who Says What Which Chanel To Whom With What Effect?". Untuk mantapnya strategi komunikasi, maka segala sesuatunya harus dipertautkan dengan komponen-komponen yang merupakan jawaban terhadap pertanyaa dalam rumus Laswell tersebut.

a. Who? (Siapa komunikatornya)

b. Says What? (Pesan apa yang digunakannya)

c. In which channel? (Media apa yang digunakannya)

d. To whom (Siapa komunikannya)

e. With what effect? (Efek apa yang diharapkannya.

Tujuan dari strategi komunikasi menurut Liliweri (Liliweri, 2011:248-249) yaitu untuk memberitahu (announcing), memotivasi (motivating), mendidik (educating), menyebarkan informasi (informating), dan mendukung pembuatan keputusan (supporting decision marketing). Adapun faktor-faktor yang mempengaruhi strategi komunikasi agar tepat sasaran menurut (Effendy, 2011:35-39) yaitu:

1) Mengenali Sasaran Komunikasi

Sebelum merencanakan komunikasi, sebaiknya perlu memahami komunikan yang akan menjadi sasaran komunikasi terlebih dahulu. Faktor yang perlu diperhatikan dalam komunikasi adalah faktor kerangka referensi, kerangka referensi seseorang terbentuk dari hasil pengalaman, pendidikan, gaya hidup, norma hidup, status sosial dan lainnya. Faktor kedua yaitu situasi dan kondisi pada saat komunikan akan menerima pesan yang disampaikan dan kondisi fisik dan psikis komunikan pada saat menerima pesan. 
2) Pemilihan Media Komunikasi

Media komunikasi banyak bentuknya seperti media tulis atau cetak, visual, aural dan audiovisual. Untuk mencapai sasaran komunikasi, seorang komunikator dapat memilih media yang sesuai bergantung pada tujuan yang dicapai, pesan yang akan disampaikan dan teknik yang akan dipergunakan.

3) Pengkajian Tujuan Pesan

Pesan komunikasi mempunyai tujuan tertentu, pesan komunikasi terdiri atas isi pesan (the content of the message) dan lambang (symbol). Isi pesan komunikasi bisa satu tetapi lambang yang dipergunakan bisa bermacam-macam seperti bahasa, gambar, warna, kial (gesture), dan sebagainya. Lambang yang paling banyak digunakan dalam komunikasi adalah bahasa karena bahasa dapat mengungkapkan pikiran dan perasaan, fakta, dan opini.

4) Peran Komunikator dalam Komunikasi

Faktor penting yang ada pada diri komunikator adalah daya tarik sumber (source attractiveness) dan kredibilitas sumber (source credibility). Seseorang komunikator akan berhasil dalam komunikasi jika pihak komunikan merasa bahwa ada kesamaan antara komunikator, sehingga komunikan bersedia taat pada pesan yang dilancaran oleh komunikator.

\section{METODE PENELITIAN}

Penelitian ini menggunakan metode penelitian kualitatif dengan pendekatan etnografi. Penelitian kualitatif adalah penelitian yang dilakukan dalam setting tertentu yang ada dalam kehidupan rill dengan maksud menginvestigasi dan memahami fenomena apa yang terjadi, mengapa terjadi dan bagaimana terjadinya (Fitrah \& Luthfiyah, 2017:45). Sedangkan etnografi merupakan suatu bangunan pengetahuan yang meliputi teknik penelitian, teori etnografi, dan berbagai macam deskripsi kebudayaan (Spradley, 1997:12).

Penelitian etnografi menurut Spadley (Spradley, 1997) dimulai dengan memilih proyek etnografi, mengumpulkan data etnografi, membuat catatan etnografis, dan menganalisis data etnografi. Pelaksanaan penelitian ini diawali dengan memilih proyek etnografi yaitu melakukan observasi secara langsung di RSU Raffa, Majenang.

Narasumber dalam penelitian ini adalah tenaga paramedis yang terdiri dari 2 dokter spesialis, 3 orang perawat dan 3 orang pasien.
Teknik pengumpulan data dalam penelitian yang digunakan sebagai dasar dalam penelitian ini adalah dengan menggunakan observasi secara langsung dan wawancara secara mendalam. Dalam penelitian ini penulis melakukan observasi secara langsung di RSU Raffa, serta melakukan wawancara mendalam dengan keyperson, yaitu dokter dan pasien. Selain itu, penulis juga melakukan wawancara mendalam dengan perawat dan satpam untuk memperlengkapi data dan dalam rangka melakukan triangulasi narasumber sebagai salah satu teknik triangulasi dalam penelitian yang penulis lakukan.

Teknik analisis data yang penulis gunakan dalam penelitian ini adalah model analisis Spadley. Model analisis data kualitatif yang dikemukakan oleh Spradley (dalam Sugiyono, 2012) ada empat tahapan dalam analisis data yaitu analisis domain, analisis taksonomi, analisis komponensial, dan analisis tema kultural. Pada tahap pertama, penulis melakukan analisis domain. Pada tahapan ini penulis berusaha untuk memperoleh gambaran umum tentang RSU Raffa untuk mendapatkan gambaran bagaimana komunikasi antar budaya yang terjadi antara dokter dengan pasien di RSU Raffa ini. Pada tahapan analisis taksonomi, penulis mulai melakukan analisis dengan berpusat pada komunikasi antar dokter dan pasien dengan memusatkan pada komunikasi antar budaya. Tahap selanjutnya, penulis mulai melakukan analisis komunikasi antar budaya yang terjadi antara dokter dan pasien yang memiliki perbedaan latar belakang budaya, bahasa dan pendidikan serta menggali hambatan-hambatan yang terjadi dalam komunikasi antar budaya ini. Berdasarkan dari hasil analisis data yang dilakukan dalam beberapa tingkatan ini, penulis kemudian mencoba memetakan strategi komunikasi antar budaya antara dokter dan pasien di RSU Raffa Majenang ini.

\section{HASIL DAN PEMBAHASAN}

\subsection{Kebudayaan Masyarakat Majenang}

Gudykunst and Kim (1992 dalam (Tubbs \& Sylvia, 2008:19) memberikan pengertian budaya sebagai suatu cara hidup yang dikembangkan dan dimiliki oleh sekelompok orang dan diwariskan dari generasi ke generasi. Dalam konteks ini, budaya dipahami sebagai aturan untuk hidup bersama dan memiliki peran yang sangat besar dalam suatu masyarakat. Pada tataran ini budaya memberikan aturan untuk bermain dalam permainan kehidupan. Hal ini seperti yang dikatakan oleh Samovar (2012:8), "Culture provides the rules for playing the game of life". 
Mengacu dari pendapat Gudykunst dan Kim serta pendapat Samovar, bagi masyarakat Majenang, budaya yang mereka miliki merupakan cara hidup yang mereka miliki dan mereka kembangkan. Budaya memberikan aturan untuk bermain dalam kehidupan. Budaya masyarakat Majenang sangat dipengaruhi oleh letak geografis mereka. Sebagai kecamatan terbesar di Cilacap, budaya dari masyarakat Majenang sangat dipengaruhi oleh budaya Jawa dan budaya Sunda. Hal ini disebabkan karena Majenang berada di posisi paling barat dari propinsi Jawa Tengah, yang berbatasan dengan propinsi Jawa Barat. Ada hal yang menarik terkait dengan budaya masyarakat Majenang. Masyarakat Majenang yang tinggal di daerah pegunungan, banyak dipengaruhi oleh budaya Sunda dan menggunakan Bahasa Sunda dalam kehidupan sehari-hari. Masyarakat yang tinggal di kota kecamatan lebih banyak dipengaruhi budaya Jawa dan menggunakan Bahasa Jawa dalam kehidupan sehari-hari. Hal ini seperti yang dikatakan oleh Wn salah satu narasumber dalam penelitian ini yang berprofesi sebagai perawat, dalam wawancara mendalam yang dilakukan pada tanggal 2 Februari 2020 mengatakan,

"Masyarakat Majenang yang tinggal di pegunungan banyak yang memeluk agama hindu dan banyak yang menganut kepercayaan kejawen. Sedangkan masyarakat yang tinggal di perkotaan, kebanyakan memeluk agama Islam".

Pernyataan narasumber $\mathrm{Az}$ ini diperkuat dengan pernyataan mas IP, salah satu narasumber dalam penelitian ini yang berprofesi sebagai Satpam di RS Raffa. Dalam wawancara mendalam pada tanggal 30 April 2020, mas IP yang asli Majenang mengatakan,

"Penduduk kota kebanyakan beragama muslim. Sedangkan penduduk yang tinggal di pegunungan masih banyak yang menganut kepercayaan Kejawen. Masyarakat yang tinggal di pegunungan ini masih banyak yang percaya kepada dukun (mereka sering menyebutnya dengan kata mbah). Pada hari-hari tertentu mereka memiliki ritual-ritual yang dilakukan berdasarkan kepercayaan yang mereka miliki. Misalnya sebelum puasa kemarin, banyak yang pergi ke kubur untuk berdoa. Tujuannya supaya yang sudah meninggal arwahnya tidak diganggu dengan arwah lain, dan biar tenang mereka di alam sana."

Dari sudut nilai-nilai, nilai-nilai yang dianut oleh masyarakat Majenang sangat dipengaruhi oleh agama dan kepercayaan yang dianut. Hal ini seperti yang disampaikan oleh Ibu Ar, salah satu pasien di RS
Raffa yang berperan sebagai narasumber dalam penelitian ini. Menurut Ibu Ar dalam wawancara mendalam 20 Januari 2020,

"Nek wong gunung kie ya akehne ijek melu kejawen. Sedulur karo tangga-tanggane nyong ya podo bae ijek do nyeluk mbah nek lagi loro, nyong ngei sajen nggo syarate, karo nyong dikon topo nang alas gunung nggo ngresiki bathine nyonge karo nggo ngentukke ilmu gen ndang waras" (Kalau orang gunung itu sebagian besar masih ikut Kejawen. Saudara dan tetangga saya hampir semua masih memanggil mbah kalau baru sakit. Saya memberikan sesaji sebagai syaratnya dan diminta bertapa di hutan untuk membersihkan batin saya, dan supaya saya mendapatkan ilmu supaya cepat sembuh).

Kejawen adalah pandangan hidup orang Jawa yang melakukan kehidupan berdasarkan moralitas atau etika dan religi yang tercermin di dalam hubungan manusia dengan Tuhan, hubungan manusia dengan manusia lainnya, dan hubungan manusia dengan alam (Soesilo, 2004). Masyarakat Majenang (khususnya yang tinggal di pegunungan), sekalipun sudah menganut agama tertentu, tapi masih banyak yang menganut kepercayaan Kejawen. Kepercayaan yang dianut ini yang kemudian membentuk cara berperilaku seperti yang diajarkan oleh budaya yang mereka hidupi. Hal ini dapat dilihat dari cara berpakaian maupun ritual-ritual yang dilakukan oleh masyarakat Majenang dengan membuat sesaji-sesaji ketika mereka mempunyai hajatan.

Herbert Blumer dalam teori interaksi simboliknya mengatakan bahwa manusia bertindak terhadap sesuatu berdasarkan makna-makna yang ada pada sesuatu itu bagi mereka. Makna itu diperoleh dari hasil interaksi sosial yang dilakukan dengan orang lain dan Makna-makna tersebut disempurnakan di saat proses interaksi sosial sedang berlangsung (dalam (Soeprapto, 2002:120). Tiga premis utama yang ditulis oleh Blumer ini menunjukkan bahwa makna diperoleh setiap individu melalui interaksi yang dilakukan. Artinya, setiap individu membangun makna melalui proses komunikasi. Proses ini melibatkan partisipasi individu-individu untuk melakukan interpretive construction (Birowo, 2019). Hal ini juga yang terjadi dengan masyarakat Majenang, khususnya yang tinggal di pegunungan. Setiap individu yang tinggal di daerah pegunungan di Majenang ini memberikan makna dalam kehidupan mereka, berdasarkan dari interpretive construction ketika mereka melakukan interaksi sosial dengan individu lainnya. Makna yang mereka peroleh dari interaksi sosial, 
akan mempengaruhi tindakan setiap individu. Tindakan yang dilakukan setiap individu dalam semua bidang (mulai dari bidang social, ekonomi bahkan sampai bidang kesehatan) akan ditentukan oleh makna yang muncul dari interaksi sosial yang dilakukan.

Edward T. Hall (dalam Liliweri, 2003:21) mengatakan bahwa antara budaya dan komunikasi dapat diibaratkan sebagai dua keping mata uang yang tidak dapat dipisahkan. Tidak akan pernah ada komunikasi tanpa ada budaya, dan tidak akan ada budaya tanpa komunikasi. Hal ini juga yang terjadi dengan masyarakat Majenang. Budaya yang mereka miliki sangat mempengaruhi komunikasi yang mereka lakukan. Sebaliknya, komunikasi yang mereka lakukan sangat mempengaruhi budaya yang terbentuk. Pengaruh antara budaya dan komunikasi ini juga berdampak ketika masyarakat Majenang berkomunikasi dengan individu lainnya, baik yang berasal dari Majenang sendiri maupun dengan masyarakat di luar kota kecamatan Majenang dalam konteks komunikasi antarbudaya.

Fred E. Jandt mengatakan "intercultural communication generally refers to face-to-face interaction among people of diverse culture" (Jandt, 1998:36). Dalam pandangan Jandt, komunikasi antarbudaya adalah komunikasi yang terjadi antara orang-orang yang memiliki latar belakang budaya yang berbeda yang terjadi secara tatap muka. Menurut Joseph A Devito, komunikasi antarbudaya ini terjadi ketika orang-orang yang terlibat dalam komunikasi memiliki kepercayaan, nilai, atau cara berperilaku kultural yang berbeda (Devito, 1997:479).

Mengacu dari pendapat Jandt dan Devito, komunikasi antarbudaya yang dilakukan oleh masyarakat Majenang sangat dipengaruhi oleh posisi geografis kota kecamatan ini. Majenang yang terletak di Jawa Tengah, dengan posisi diujung barat Jawa Tengah dan berdekatan dengan Jawa Barat. Posisi geografis ini membuat masyarakat Majenang berada dalam satu kondisi untuk berinteraksi dan berkomunikasi dengan masyarakat yang memiliki budaya yang berbeda. Di satu sisi, pada saat tertentu masyarakat Majenang di posisikan harus berkomunikasi dengan masyarakat yang memiliki budaya Jawa, di sisi yang lain, masyarakat Majenang dikondisikan untuk berkomunikasi dengan masyarakat yang memiliki latar belakang budaya Sunda. Pada tataran ini terjadi pertemuan antar budaya Jawa dan budaya Sunda yang akhirnya membentuk komunikasi antarbudaya yang terjadi dalam kehidupan masyarakat Majenang. Komunikasi ini dipengaruhi oleh kepercayaan, nilai dan cara berperilaku sesuai dengan perpaduan budaya Jawa dan budaya Sunda yang mereka anut, seperti yang dikatakan oleh DeVito.

Komunikasi antarbudaya dilakukan dalam semua bidang, karena budaya itu sendiri mempunyai peran yang sangat besar dalam semua bidang kehidupan manusia. Hal ini seperti yang dikatakan oleh (Samovar, 2012),

Culture is an extremely popular and increasingly overused term ini contemporary society. Culture has been linked to such fields as corporate, management, health care, psychology, education, public relations, marketing and advertising (Samovar, 2012: 10)

Menurut Samovar, budaya mempunyai peran penting dalan pelayanan kesehatan, hal ini disebabkan karena pelayanan kesehatan dapat berjalan dengan efektif ketika pelayanan itu dilakukan dengan menggunakan pendekatan sesuai dengan budaya dari pasien. Pada tataran inilah komunikasi antarbudaya menjadi satu hal yang sangat penting, antara paramedis dengan pasien.

\subsection{Dokter sebagai komunikator dalam proses pelayanan kesehatan}

Komunikasi antarbudaya juga terjadi antara dokter dengan pasien di RS Raffa, Majenang. Yang menarik dari komunikasi antarbudaya yang terjadi di rumah sakit ini disebabkan karena perbedaan budaya antara dokter-dokter dan pasien. Dokter-dokter yang ada di rumah sakit ini sebagian besar berasal dari kota-kota di sekitar Majenang seperti dari Yogyakarta, Jakarta dan kota-kota lainnya. Perawat dan tenaga medis lainnya berasal dari kota kecamatan Majenang, sedangkan pasien yang datang berobat ke rumah sakit ini sebagian besar berasal dari masyarakat yang tinggal di pegunungan yang menggunakan Bahasa Sunda kasar, dengan latar belakang kepercayaan Kejawen. Kondisi ini yang memunculkan komunikasi antarbudaya antar dokter dan pasien.

Charley H Dood (dalam Darmastuti, 2013:64) mengatakan bahwa komunikasi antarbudaya meliputi komunikasi yang melibatkan peserta komunikasi yang mewakili pribadi, antarpribadi maupun kelompok dengan menekankan pada perbedaan latar belakang kebudayaan yang mempengaruhi komunikasi para peserta atau partisipan komunikasi. Komunikasi antarbudaya yang terjadi di RSU Raffa Majenang ini juga melibatkan peserta komunikasi yang mewakili pribadi, antarpribadi maupun kelompok dengan 
penekanan pada perbedaan latar belakang kebudayaan yang akhirnya mempengaruhi para peserta atau partisipan komunikasi pada saat mereka berkomunikasi. Hal ini dapat kita lihat dari tindak komunikasi yang dilakukan oleh setiap peserta komunikasi pada saat mereka sedang berkomunikasi, baik dalam komunikasi antar pribadi maupun dalam komunikasi kelompok.

Tindak komunikasi yang terjadi antara dokter dan pasien di RSU Raffa ini terjadi dalam dua bentuk komunikasi, yaitu komunikasi verbal dan non-verbal. Komunikasi verbal adalah komunikasi yang dalam menyampaikan pesannya dengan menggunakan secara lisan dan tertulis (Effendy, 1998:7). Proses komunikasi verbal dokter dan pasien dimulai di ruang rawat inap. Proses komunikasi verbal yang terjadi antara dokter dan pasien yaitu dimulai dengan dokter mengucapkan salam, menanyakan kabar, serta memeriksakan kondisi pasien. Hal tersebut sesuai seperti yang dikatakan dokter Dh dalam wawancara mendalam pada tanggal 21 Januari 2020, merupakan salah satu dokter spesialis tulang di rumah sakit ini,

"Biasanya ketika visit ke bangsal gitu saya ngucapin salam dulu seperti "selamat pagi atau selamat siang Pak/Bu? gimana keadaannya?”. Kemudian dilanjutkan dengan memeriksa kondisi pasien lalu saya memberitahukan tentang perkembangan kesehatannya gimana. Kalo untuk bahasanya saya pake Bahasa Indonesia, saya tidak bisa Bahasa Jawa Ngapak, tapi kadang ada sih saya nyelipin sedikit kata-kata bahasa Jawa Ngapaknya seperti "inyong” yang berarti saya, lalu "kencot" yang berarti lapar. Ya hanya kata-kata dasar sih".

Menurut dokter Dh, komunikasi verbal dalam komunikasi antarbudaya yang dilakukan dengan pasien adalah dengan memberikan perhatian melalui ucapan selamat pagi dan menggunakan Bahasa Indonesia yang diselingi dengan Bahasa ngapak, sekalipun itu hanya Bahasa yang dasar-dasar saja. Tujuannya adalah untuk membangun kedekatan dengan pasien. Komunikasi verbal ini juga dilakukan oleh dokter Artt, salah satu dokter spesialis bedah yang ada di RSU Raffa ini. Dalam wawancara mendalam dengan penulis pada tanggal 22 Januari 2020, dokter yang berasal dari Yogyakarta ini mengatakan,

"Kalo visit itu mengucapkan salam," Selamat pagi/siang Bapak/Ibu? setelah "memeriksakan kondisi pasien, lalu setelah itu biasanya saya menanyakan apa saja aktivitas yang dilakukan di rumah. Nanti kalo pasiennya mau cerita saya dengarkan. Saya ngobrolnya pake Bahasa Indonesia tapi sering saya campur dengan bahasa Jawa Ngapak, karena saya sudah lumayan lama disini jadi saya mulai ngerti dikit-dikit bahasa sini (Jawa), untuk meningkatkan lagi makanya saya terapin aja ketika visite".

Penggunaan bahasa daerah disela-sela Bahasa Indonesia yang digunakan oleh dokter, menjadi salah satu cara yang dilakukan dalam komunikasi antarbudaya antara dokter dengan pasien. Langkah ini dilakukan untuk membangun kedekatan dan supaya pasien merasa nyaman. Dokter-dokter menggunakan Bahasa Indonesia, hal ini seperti penelitian yang dikatakan dalam hasil penelitian yang dilakukan oleh (Hadi, 2017), hendaknya setiap pelaku komunikasi antarbudaya senantiasa menanamkan sikap toleransi dan pemikiran yang positif antar sesama.

Bentuk komunikasi kedua yang dalam komunikasi antarbudaya antara dokter dan pasien di RSU Raffa adalah komunikasi non-verbal. Komunikasi non verbal adalah komunikasi dengan menggunakan gejala yang menyangkut dengan gerak-gerik (gestures), sikap (postures, ekspresi wajah (facial expressions, pakaian yang bersifat simbolik, isyarat dan gejala yang sama yang tidak menggunakan bahasa lisan dan tulisan (Effendy, 2004:28). Dokter Dh, dalam wawancara mendalam pada tanggal 21 Januari 2020 yang merupakan salah satu narasumber dalam penelitian ini mengatakan,

"Saat mengucapkan salam saya sembari senyum supaya pasien merasa dihargai. Lalu yang tidak boleh ketinggalan itu kontak mata, karena saat itu kita secara tidak langsung membangun kepercayaan si pasien tersebut terhadap kita. Saya juga biasanya menggunakan gerakan-gerakan tangan agar pasien dapat mengerti apalagi pasien banyak yang tidak bisa Bahasa Indonesia, jadi supaya memudahkan mereka mengerti. Oiya anggukan kepala juga biasanya kalau pasien lagi cerita saya menganggukkan kepala sebagai tanda mengerti"

Hampir sama dengan pendapat dokter Dh, terkait dengan komunikasi non-verbal, dalam wawancara mendalam dengan peneliti pada tanggal 21 Januari 2020, dokter Artt mengatakan,

"Kalau sudah ketemu pasien gitu, ya bawaannya harus senang, senyum, apalagi kan saya menanganinya orang yang habis operasi jadi harus happy, kita tenaga medis harus bawa energi positif ke mereka. Selain itu biasanya saya kasih sentuhan gitu seperti saat memeriksa suhu tubuh pasien, maupun sedang memberikan kata-kata semangat sambil menepuk pundak pasien" 
Dalam komunikasi antarbudaya antara dokter dengan pasien ini, komunikasi nonverbal digunakan untuk membangun kepercayaan pasien, memotivasi pasien, memberikan semangat bahkan sebagai bentuk penghargaan. Hal ini seperti yang dikatakan Ahmad Subandi, bahwa respon dengan istilah balik (feedback) dalam suatu tindak komunikasi yang memiliki peranan atau pengaruh yang besar dalam menentukan baik atau tidaknya suatu komunikasi (Subandi, 1982:50).

\subsection{Pasien sebagai komunikan dalam pelayanan kesehatan}

Komunikasi verbal dan non-verbal juga dilakukan oleh pasien pada saat terjadi komunikasi antarbudaya antara paramedis dengan pasien. Bapak As, salah satu pasien dokter Artt di RSU Raffa dalam wawancara mendalam pada tanggal 17 Januari 2010 mengatakan, "Ya ngerukna, nek nyong ditakoni ya njawab di rewangi perawat karo anggota keluarga" (Ya dengarin, kalo ditanya ya dijawab. tapi dibantu perawat atau anggota keluarga).

Berbeda dari Bapak As, Ibu Ar merespon dengan cara yang berbeda. Dalam wawancara dengan peneliti pada tanggal 20 Januari 2020, Ibu Ar salah satu pasien yang ditangani oleh dr. Dh mengatakan, "Nyonge meneng bae karo ngrungokna nek doktere njelasna" (Saya diam saja dan mendengarkan waktu dokternya menjelaskan).

Komunikasi antarbudaya tidak lepas dari suasana dari setiap peristiwa komunikasi yang terjadi. Menurut dokter $\mathrm{Dh}$, dalam wawancara mendalam pada tanggal 21 Januari 2020, suasana yang tercipta selama proses komunikasi antara dokter dan pasien dalam pelayanan kesehatan di RSU Raffa ini adalah suasana yang tenang. Hal ini seperti yang dikatakan dokter $\mathrm{Dh}$,

"Biasanya saya visite itu ketika pagi hari, suasananya itu tenang dan kondusif ya, karena kan pasiennya juga baru bangun jadi belum banyak anggota keluarga di ruangan".

Pernyataan tersebut juga didukung oleh Ibu Ar. Dalam wawancara mendalam pada tanggal 20 Januari 2020, Ibu Ar mengatakan, Yaa adem ayem karo sepi, Nyonge pas lagi tangi seduluran durung pada teka" (Ya tenang, sepi juga, saya baru bangun juga dan belum banyak keluarga)

Suasana santai dalam peristiwa komunikasi ketika sedang visit juga diciptakan oleh dokter Art. Dalam wawancara mendalam pada tanggal 22 Januari 2020, dokter Art mengatakan, Suasananya sih santai ya, soalnya saya juga selipin candaan sedikit saat ngobrol dengan pasien."

Pernyataan dokter Art ini dipertegas dengan bapak As, pasien yang ditangani dokter Art. Dalam wawancara mendalam ini bapak As mengatakan, "Enak banget, suasane yo nyante" (Enak suasananya, santai).

Berdasarkan hasil wawancara dengan beberapa narasumber dalam penelitian ini, komunikasi antarbudaya yang berlangsung antara dokter dan pasien dilakukan dalam dua bentuk komunikasi, yaitu komunikasi verbal dan non-verbal. Komunikasi verbal yang terjadi dengan menggunakan Bahasa Indonesia yang diselingi dengan Bahasa Jawa Ngapak. Penggunaan Bahasa Jawa Ngapak diantara Bahasa Indonesia dilakukan sebagai cara untuk membangun kedekatan antara dokter dan pasien. Komunikasi non-verbal dilakukan dengan menggunakan ekspresi, kontak mata, sikap dan gerakan tubuh (gesture). Komunikasi non-verbal ini dilakukan dengan tujuan untuk membangun kepercayaan pasien, memotivsi, memberikan semangat bahkan memberikan penghargaan. Suasana santai yang dibangun dalam setiap peristiwa komunikasi antar dokter dan pasien dilakukan dalam rangka membangun suasana yang kondusif supaya pasien merasa tenang dan nyaman, sehingga tidak terjadi ketegangan supaya pasien cepat sembuh.

\subsection{Faktor Penghambat dalam proses pelayanan Kesehatan di RSU Raffa}

Chaney \& Martin (2004:11) mengatakan ada beberapa hambatan yang sering terjadi dalam komunikasi antarbudaya, yaitu hambatan fisik (Physical), hambatan budaya (culturan), hambatan persepsi (motivationnal), hambatan pengalaman (experiential), hambatan emosi (emotional), hambatan bahasa (linguistic), hambatan nonverbal dan hambatan kompetisi (competition). Hambatan-hambatan ini juga yang terjadi dalam komunikasi antarbudaya antara dokter dan pasien di RSU Raffa.

Novinger (dalam Ridwan, 2016:114) mengatakan bahwa dalam proses komunikasi antarbudaya, reaksi negatif dan evaluasi individu terhadap sebuah budaya dapat menciptakan hambatan komunikasi. Itu sebabnya, memahami budaya lain yang dimiliki oleh partisipan komunikasi pada saat kita berkomunikasi dalam komunikasi antarbudaya menjadi satu hal yang sangat penting. Pengetahuan yang kita miliki tentang komunikasi antarbudaya, serta kemampuan kita untuk menggunakan komunikasi antarbudaya secara efektif, 
dapat membantu menjembatani perbedaan budaya, mengurangi masalah dan membantu mencapai hubungan yang lebih harmonis dan produktif. Hal ini seperti yang dikatakan Samovar,

A knowlage of intercultural communication, and the ability to use it effectively, can help bridge cultural differences, mitigare problem and assist in achieving more harmonious, productive relations (Samovar, 2012:8)

Ada tiga hambatan yang sangat menonjol dalam komunikasi antarbudaya yang terjadi antara dokter dan pasien. Ketiga hambatan tersebut adalah hambatan bahasa, hambatan budaya dan hambatan persepsi.

\subsubsection{Hambatan Bahasa.}

Hambatan bahasa (linguistic), terjadi karena pengirim pesan (sender), dan penerima pesan (receiver) menggunakan bahasa berbeda atau penggunaan katakata yang tidak dimengerti oleh penerima pesan (Chaney \& Martin, 2004:11). Dalam proses pelayanan kesehatan di RSU Raffa, hambatan yang paling sering ditemukan yaitu bahasa. Menurut (Keraf \& Gorys, 1997:1) bahasa adalah alat komunikasi antara anggota masyarakat berupa simbol bunyi yang dihasilkan oleh alat ucap manusia. Bahasa memudahkan seseorang dalam berkomunikasi baik itu dengan orang yang berkebudayaan sama maupun dengan orang yang berbeda budaya. Apabila dalam komunikasi tersebut tidak tercapai kesamaan makna pesan, maka bahasa dapat menjadi suatu hambahan dalam komunikasi. Hal ini juga yang dialami dokter RSU Raffa yang selalu berinteraksi dengan pasien suku Jawa yang tidak bisa bahasa Indonesia dengan baik. Akibatnya dalam proses pelayanan kesehatan dokterdokter yang melayani pasien agak kesulitan ketika menyampaikan informasi. Hal ini seperti yang disampaikan oleh dokter Dh selaku dokter yang lebih sering bertemu dengan pasien yang berlatar belakang budaya berbeda dengan beliau, dalam wawancara pada tanggal 21 Januari 2020, beliau mengatakan:

"Selama saya berpraktek di Raffa, hambatan yang paling banyak dijumpai itu karena perbedaan bahasa. Mayoritas pasien yang datang ke sini (RSU Raffa) kan dari gunung sana dan mereka itu banyak yang tidak bisa Bahasa Indonesia, sedangkan kami tim medis di sini juga mayoritas dari luar daerah dan kami juga tidak terlalu bisa bahasa Jawa Ngapak atau Sunda".

Saat berkomunikasi dengan pasien, dokter mengalami kesulitan ketika menyampaian informasi terkait kondisi kesehatan pasien karena pasien hanya bisa berbahasa Jawa Ngapak dan tidak mengerti ketika dokter menjelaskan. Hal ini disebabkan karena mayoritas dokter yang bertugas di RSU Raffa Mejenang ini merupakan pendatang dan bukan penduduk asli Majenang. Oleh karena itu, informasi yang disampaikan dokter menjadi terhambat. Hal ini juga dibenarkan oleh Ibu Ar selaku pihak pasien yang ditangani oleh dr. Dh. Dalam wawancara mendalam pada tanggal 20 Januari 2020 Ibu Ar mengatakan:

"Nek nyonge ngobrol karo doktere, doktere kadang njawabe ora lancar dadine nyong nek arep ngei weroh yo bingung" (Kalau ngobrol sama dokternya, dokternya tidak lancar bahasa Jawa jadi agak bingung juga kalau mau kasih tau sesuatu).

Tanggapan serupa juga disampaikan Bapak As dalam wawancara dengan peneliti pada tanggal 17 Januari 2020, mengatakan:

"Angel nek nyong arep ngomong langsung nang doktere seringan nganggone bahasa medis seng nyong ora mudeng, nyong angel nek kon ngomong Indonesia, kadang anake nyong seng ngerungokna. Nek lagi metu ya paling nyonge mantuk-mantuk bae" (sulit kalau mau ngomong langsung ke dokternya, kadang bahasa-bahasanya bahasa dokter, susah ngertinya, apalagi saya tidak lancar kalau Bahasa Indonesia, kalau misalnya ada anak saya, bisa membantu. Tapi kalo lagi ga ada, saya paling ngangguk-ngangguk aja)

Barbara Ballis Lal (dalam Littlejohn, 2012:231) mengatakan manusia memahami pengalaman mereka melalui makna-makna yang ditemukan dalam simbol-simbol dari kelompok utama mereka dan bahasa merupakan bagian penting dalam kehidupan sosial. Mengacu dari pendapat Barbara Ballis Lal, bahasa menjadi bagian yang sangat penting dalam kehidupan sosial, termasuk dalam komunikasi antarbudaya antara dokter dan pasien. Ketika bahasa tidak bisa menjadi media yang menghubungkan antara komunikator dan komunikan, maka yang terjadi adalah berhentinya proses komunikasi yang terjadi. Hal ini seperti yang dikatakan oleh Ibu Ar, salah satu pasien di RSU Raffa yang mengatakan,

"Nek nyonge ngobrol karo doktere, doktere kadang njawabe ora lancar dadine nyong nek arep ngei weroh yo bingung" (Kalau ngobrol sama dokternya, dokternya tidak lancar Bahasa Jawa jadi agak bingung juga kalau mau kasih tau sesuatu). 
Hambatan bahasa merupakan hambatan yang sering terjadi dalam pelayanan kesehatan. Hal ini seperti yang dituliskan dari hasil penelitian yang dilakukan oleh Simanjuntak pada tahun 2016 dengan judul 'Pelayanan Kesehatan dalam pendekatan komunikasi antarbuday (Studi fenomenologi pelayanan kesehatan Dokter kepada Pasien di RSUP H. Adam Malik Medan)'. Hasil dari penelitian ini menunjukkan bahwa hambatan antarbudaya seperti bahasa, pengalaman, hambatan fisik, kompetisi dan hambatan non-verbal merupakan hambatan yang muncul dalam pelayanan kesehatan di RSUD H. Adam Malik. Karakter dokter dan pasien serta faktor situasional turut memberikan pengaruh pada proses pelayanan kesehatan (Simanjuntak, 2016).

\subsubsection{Hambatan Persepsi.}

Hambatan persepsi (motivational), berkaitan dengan tingkat motivasi dari pendengar. Artinya, pendengar yang menerima pesan ingin menerima pesan tersebut atau tidak mempunyai motivasi sehingga dapat menjadi hambatan komunikasi (Chaney, 2004:11). Persepsi adalah pengamatan tentang objek, peristiwa atau hubungan-hubungan yang diperoleh dengan menyimpulkan informasi dan menafsirkan pesan (Rakhmat, 2007). Dalam wawancara yang dilakukan dengan peneliti pada tanggal 22 Januari 2020, dokter Art mengatakan:

"Pasien menganggap bahwa ketika mereka masuk rumah sakit, mereka berpikirnya harus sembuh hanya dalam beberapa hari, sedangkan secara medis dalam proses penyembuhan itu membutuhkan waktu yang tidak singkat. Nah nanti dampaknya itu kalau misalnya udah tiga atau empat hari belum bisa pulang, akhirnya pasien ataupun keluarganya akan neror kita (dokter atau perawat) dengan segala pertanyaan seperti "kapan pulang", "kenapa tidak sembuh-sembuh", dan lain sebagainya. Kita biasanya nenangin dengan bilang kalau mereka pasti sembuh asalkan harus rutin minum obat."

Tindakan yang dilakukan oleh pasien-pasien yang melakukan perawatan di RSU Raffa ini tidak lepas dari pemahaman dan penafsiran mereka tentang rumah sakit, pengobatan dan proses kesembuhan. Pemahaman dan penafsiran mereka ini sangat terkait dengan pengetahuan yang mereka miliki. Tindakan manusia itu didasarkan pada penafsiran mereka, dimana objek dan tindakan yang berhubungan dalam situasi yang dipertimbangkan dan diartikan (Barbara Ballis Lal dalam Littlejohn, 2012). Pada tataran ini, persepsi mempunyai peranan yang sangat menentu- kan. Persepsi merupakan proses internal yang diakui individu dalam menyeleksi, dan mengatur stimuli yang datang dari luar. Stimuli itu ditangkap oleh indera, secara spontan pikiran dan perasaan kita akan memberi makna atas stimuli tersebut. Secara sederhana persepsi dapat dikatakan sebagai proses individu dalam memahami kontak atau hubungan dengan dunia sekelilingnya (Aw, 2010:107)

Bapak As dalam wawancara dengan peneliti pada tanggal 17 Januari 2020 mengatakan:

"Nyong ya kesel.lha nyong wes melui seng dokter ngomong, dikon ngombe obat seng di wei iyo manut, nyong yo madang seng di wei rumah sakit. Tapi nyong during mari-mari iki wes patang dino neng kene. Jarene doktere sedilut ngkas mari, tapi buktine ya during" (Iya lah, kesal. Soalnya saya tuh sudah mengikuti apa yang mereka (dokter) bilang, seperti minum obat yang mereka kasih, saya juga makan kok makanan yang dikasih. Tapi sampe sekarang saya masih disini (RSU Raffa) aja. Udah empat hari saya disini. Kata dokternya waktu itu sebentar lagi sembuh, sebentar lagi sembuh, tapi buktinya belum sembuh juga, sudah bosan saya disini).

Persepsi menjadi satu hal yang sangat penting dalam sebuah komunikasi, termasuk dalam proses komunikasi yang terjadi antara dokter dan pasien di RSU Raffa. Hal ini ditunjukkan dari setiap simbol yang dikirimkan oleh komunikator (dalam hal ini dokter) tidak langsung dapat diterima dan dengan mudah dimengerti oleh komunikan. Proses interpretasi dan belajar dari pengalaman merupakan hal utama dalam memahami komunikasi atau simbol-simbol yang disampaikan.

Selain itu, perbedaan persepsi tidak jarang terjadi yang disebabkan karena pandangan negatif yang dimiliki oleh partisipan komunikasi lainnya yang disebabkan karena ketidakjelasan makna. Hal ini dapat dilihat dari respon As yang agak jengkel dengan kondisinya dan mengatakan,

"Nyong ya kesel, lha nyong wes melui seng dokter ngomong, dikon ngombe obat seng di wei iyo manut, nyong yo madang seng di wei rumah sakit. Tapi nyong durung mari-mari iki wes patang dino neng kene. Jarene doktere sedilut ngkas mari, tapi buktine during".

Respon ini muncul sebagai akibat persepsi yang muncul berdasarkan dari pandangan negatif yang dia miliki. Pandangan negatif ini bisa jadi disebabkan 
karena pasien tersebut tidak paham dengan pesan yang disampaikan oleh dokter. Untuk mengatasi perbedaan persepsi ini, Maya Hervia Putri dalam penelitiannya yang dilakukan pada tahun 2014 dengan judul 'Strategi Komunikasi Antarbudaya dalam mengurangi stereotype negatif terhadap suku Batak di Rusunawa Keudah, Banda Aceh' mengatakan bahwa hambatan persepsi ini disebabkan karena respon partisipan komunikasi. Hasil penelitian ini mengatakan dalam proses komunikasi antarbudaya, setiap individu cenderung menarik kesimpulan terhadap lawan bicaranya berdasarkan persepsi awal yang mereka terima sebagai bentuk penafsiran makna yang mereka dapatkan dari proses komunikasi diantara partisipan komunikasi (Putri, 2014:81)

\subsubsection{Hambatan Budaya.}

Hambatan budaya (cultural), berasal dari etnik yang berbeda, agama, dan perbedaan sosial antara budaya satu dan budaya lainnya (Chaney \& Martin, 2004:11). Koentjaraningrat (Warsito, 2012:99) mengatakan, nilai budaya terdiri dari konsepsi-konsepsi yang hidup dalam alam fikiran sebahagian besar warga masyarakat dalam hal-hal yang mereka anggap amat mulia. Sistem nilai yang ada dalam suatu masyarakat dijadikan orientasi dan rujukan dalam bertindak. Oleh karena itu, nilai budaya yang dimiliki seseorang mempengaruhinya dalam mengambil alternatif, caracara, alat-alat dan tujuan-tujuan pembuatan yang tersedia. Kepercayaan masyarakat Jawa di Majenang terhadap dukun menjadi salah satu faktor yang mempengaruhi proses pelayanan kesehatan di RSU Raffa. Sebagai contoh, dalam kehidupan sehari-hari yang terjadi di masyarakat Majenang yang tinggal di pegunungan, ketika ada salah satu dari antara mereka yang sakit, maka tindakan pertama yang mereka lakukan adalah pergi ke dukun. Dalam perkembangannya, setelah mereka pergi ke dukun dan belum sembuh juga, atau bahkan makin parah, maka mereka baru mengambil keputusan untuk berobat ke rumah sakit.

Kondisi ini dibenarkan oleh dokter Dh yang seringkali menerima pasien dalam kondisi yang sudah parah karena tidak segera berobat ke rumah sakit, tetapi berobat ke dukun terlebih dahulu. Dalam wawancara mendalam yang dilakukan peneliti pada tanggal 21 Januari 2020 beliau mengatakan:

"Iya, jadi biasanya kalau ada pasien yang dari gunung datang mereka itu biasanya sudah sakit lama, jadi mereka sudah pergi ke dukun dulu jika disana tidak membaik baru datang kesini (RSU Raffa), lalu ada juga beberapa keluarga pasien yang suka ngundang dukun untuk di doain disini, kita juga tidak mempermasalahkan ya, yang penting obatnya diminum. Ada beberapa juga pasien yang ketika memang harus ditangani dengan serius karena sudah parah justru anggota keluarga malah menolak alasannya karena kata "mbah" itu tidak harus dioperasi, tapi kita ngobrol pelan-pelan, meyakinkan mereka dengan kasih tau manfaatnya barulah mereka mau nurut"

Kepercayaan terhadap dukun juga masih diyakini oleh salah satu narasumber yaitu Bapak As. Dalam wawancara yang dilakukan dengan peneliti pada tanggal 17 Januari 2020, beliau mengatakan:

"Neng desane nyong, Cijati emang ijek akeh dukun e seng iso ngobati wong-wong loro, nyong sering lunga maring mbah nek eneng seng loro. Ancen wes dadi "syarat" nek nggo warga neng kana sih, nek jare wong-wong nang kana, kudu nang mbah disit nek arep sehat wal afiat, percuma nek mangkat nag rumah sakit tapi during nag mbah disit, pamali. Nek arep nang mbah deweke di kongkon nggawa banyu sak botol karo gula mbek duit sak ikhlase, mengko banyune di wacak na mantra trus kon ngombe. Mengko nek during mari baru nang rumah sakit" (di desa Cijati kampung saya tuh masih banyak "mbah" (dukun) yang menjadi pengobatan alternatif warga kampung. Saya juga sering pergi ke "mbah" kalau anggota keluarga ada yang sakit. Memang sudah menjadi "syarat" warga disana sih, kata orang-orang harus ke "mbah" dulu supaya di ridhoi, percuma kalo ke rumah sakit dulu kalau ke belum ke "mbah", pamali. Kalau mau manggil syaratnya kita cuma disuruh bawa satu botol air putih trus bawa gula sama uang secukupnya, nanti air tersebut dibacakan doadoanya dia (dukun) trus kita minum. Nanti kalau ga sembuh-sembuh ya sudah kita ke rumah sakit).

Kepercayaan yang dianut oleh masyarakat Majenang yang tinggal di gunung, membuat mereka memprioritaskan pergi ke dukun terlebih dulu baru ke rumah sakit. Kondisi ini juga diperjelas dengan pendapat dokter Art dalam wawancara mendalam pada tanggal 21 Januari 2020, mengatakan,

"Wah, kalo soal mistis-mistis gitu mah disini memang banyak pasien yang masih menganut demikian. Soalnya masyarakat disini memang mayoritas masih nganut Kejawen gitu, jadi ya beginilah memang di Majenang, hehe." 
Perbedaan budaya, bahasa dan persepsi menjadi hambatan-hambatan yang membuat komunikasi antarbudaya yang terjadi antara dokter dan pasien di RSU Raffa tidak berjalan dengan efektif. Oleh karena itu, memahami secara jelas dan komprehensip berbagai hambatan maupun rintangan dalam komunikasi antarbudaya adalah jembatan kearah perwujudan komunikasi antarbudaya yang efektif (Turnomo, 2005:56).

\subsection{Strategi Komunikasi antarbudaya dokter kepada pasien}

Liliweri (2003:5) mengatakan bahwa esensi dari komunikasi itu terletak pada proses, yakni suatu aktivitas yang 'melayani' hubungan antara pengirim dan penerima pesan melampaui ruang dan waktu. Ketika proses ini mengalami suatu hambatan, maka proses itu tidak akan berjalan dengan baik. Begitu juga yang terjadi dalam komunikasi antarbudaya yang antara dokter dan pasien di RSU Raffa. Ketika proses komunikasi antarbudaya yang terjadi mengalami hambatan, maka komunikasi yang terjadi antara paramedis dengan pasien di RSU Raffa ini juga tidak akan berjalan secara efektif. Oleh karena itu dipikirkan cara untuk mengatur bagaimana pesan itu bisa sampai kepada pasien, karena sebetulnya komunikasi itu sendiri adalah manajemen pesan dengan tujuan menciptakan makna. Hal ini seperti yang dikatakan oleh Griffin, Communication is the management of messages with the objective of creating meaning" (Griffin, 2003).

Dalam penerapan sehari-hari, manajemen pesan juga sering disebut dengan strategi komunikasi. Liliweri (Liliweri, 2011:240) mengatakan strategi komunikasi adalah strategi untuk menciptakan komunikasi yang konsisten, komunikasi yang dilakukan berdasarkan satu pilihan (keputusan) dari beberapa opsi komunikasi. Rogers (dalam Cangara, 2014:64) memberi batasan pengertian strategi komunikasi sebagai suatu rancangan yang dibuat untuk mengubah tingkah laku manusia dalam skala yang lebih besar melalui transfer ide-ide baru. Seorang pakar perencanaan komunikasi Middleton (Cangara, 2014:64) membuat definisi dengan menyatakan bahwa strategi komunikasi adalah kombinasi terbaik dari semua elemen komunikasi mulai dari komunikator, pesan, saluran (media), penerima sampai pada pengaruh (efek) yang dirancang untuk mencapai tujuan komunikasi yang optimal."

Berdasarkan observasi langsung dan wawancara mendalam yang dilakukan oleh penulis, ada beberapa strategi komunikasi yang dilakukan oleh dokter kepada pasien dalam komunikasi antarbudaya di RSU Raffa, Majenang ini. Strategi tersebut adalah: pertama, strategi dalam mengatasi hambatan bahasa; kedua, strategi dalam mengatasi hambatan budaya dan ketiga, strategi dalam mengatasi hambatan persepsi.

\subsection{Strategi dengan menggunakan penerjemah.}

Dalam menangani perbedaan bahasa, strategi yang dilakukan oleh paramedis yang ada di RSU Raffa ini adalah dengan menggunakan penerjemah. Menggunakan penerjemah merupakan salah satu strategi yang digunakan. Hal ini seperti yang dijelaskan oleh dokter $\mathrm{Dh}$ dalam wawancara mendalam dengan peneliti pada tanggal 21 Januari 2020. Dalam wawancara mendalam ini, dokter Dh mengatakan,

"Selama ini, kami dari pihak tenaga medis terutama dokter solusinya adalah menggunakan penerjemah, biasanya yang bantuin terjemahkan itu perawat atau tidak anggota keluarga pasien".

Hal yang sama juga disampaikan oleh Ibu Ar, salah satu pasien yang menjadi narasumber dalam penelitian ini. Dalam wawancara mendalam ini, ibu Ar mengatakan,

"Doktere biasane nggawa perawate kon nerjemana seng kadang nyonge ora mudeng" (Iya, doktemya biasanya minta tolong asistennya (perawat) dalam menerjemahkan bahasa yang saya tidak paham)

Strategi dengan menggunakan penerjeman ini juga dilakukan oleh dokter Art. Walaupun mengetahui dan paham sedikit-sedikit dengan bahasa Jawa, dokter Art juga menggunakan penterjemah. Cara yang dilakukan oleh dokter Art adalah dengan meminta bantuan kepada keluarga pasien atau perawat untuk menterjemahkan bahasa pasien. Hal ini seperti yang dikatakan oleh dokter Art dalam wawancara dengan peneliti pada tanggal 21 Januari 2020,

"saya tetap membutuhkan teman-teman dari perawat atau tidak anggota keluarga pasien yang bisa berbahasa Indonesia, karena saya belum lancar bahasa Jawa Ngapak, jadi saya masih tetap butuh translator".

Bapak As, salah satu pasien dokter Ar mempertegas strategi yang dilakukan oleh dokter Ar dalam mengatasi hambatan bahasa ini. Dalam wawancara mendalam dengan peneliti, bapak As mengatakan, 
"Doktere senenge takon nang kancane nek ora mudeng, kadang nek pas ana anake nyong ya anake nyong ngewangi njelasna" (dokternya suka bertanya ke temannya (perawat) kalau tidak mengerti atau tidak bertanya ke anak atau keponakan saya kalau sedang disini).

Sejak ada bantuan penerjemah, dokter-dokter yang ada di RSU Raffa menjadi lebih terbantu dalam proses pelayanan kesehatan dengan pasien yang tidak bisa berbahasa Indonesia.

Edukasi Pasien. Strategi kedua yang digunakan oleh paramedis dalam mengubah persepsi pasien tentang proses pemulihan adalah dengan mengedukasi pasien. Edukasi ini dilakukan pada saat awal ketika pasien diputuskan untuk dirawat inap. Hal ini seperti yang dijelaskan oleh dokter Dh dalam wawancara mendalam dengan penulis. Dalam wawancara mendalam ini dokter Dh mengatakan,

"Untuk upaya yang kami lakukan terhadap persepsi pasien yaitu kami menjelaskan di awal tentang rentang waktu proses pemulihan sakit yang di derita pasien contohnya untuk pemulihan pasca operasi fraktur (patah tulang) paling tidak satu sampai dengan dua bulan, jadi pasien tidak khawatir kok belum sembuhsembuh, selain itu setiap visite kami juga selalu menjelaskan ke mereka (pasien)"

Hal yang serupa juga disampaikan dokter Art dalam wawancara dengan peneliti pada tanggal 24 April 2020 via telepon. Dalam wawancara mendalam ini dokter Art mengatakan,

"Kalau saya pribadi karena saya dokter bedah, rata-rate pasien saya operasi. Nah, sebelum operasi saya selalu menjelaskan kalo untuk pasca operasi itu, pemulihan paling minim satu minggu, jadi saat saya visite pasien tidak bertanya lagi".

\subsection{Mempelajari budaya dan karakter pasien.}

Strategi lain yang digunakan oleh paramedis dalam menghadapi hambatan persepsi dari pasien adalah dengan cara mempelajari budaya serta karakter pasien. Hal ini seperti yang dikatakan oleh dokter Dh dalam wawancara mendalam pada tanggal 21 Januari 2020,

"Saya suka tanya teman-teman perawat biasanya bagaimana karakter masyarakat disini (Majenang), lalu bertanya juga pengalaman apa saja sih yang pernah mereka alami dulu selama berhadapan dengan pasien suku Jawa Ngapak ini”.
Hal yang sama juga dilakukan oleh dokter Art selama berpraktik di RSU Raffa. Dalam wawancara mendalam pada tanggal22 Januari 2020 beliau mengatakan,

"Saya walaupun sudah cukup lama berada di Majenang, tapi saya masih agak susah sih paham sama karakter mereka, oleh karena itu saya tetap terus mencari informasi terkait kebudayaan masyarakat Majenang terutama pasien-pasien yang berobat di RSU Raffa".

Upaya yang dilakukan oleh dokter-dokter yang ada di RSU Raffa ini bertujuan untuk mengidentifikasi bagaimana keadaan masyarakat Majenang. Dokterdokter yang bertugas di RSU Raffa Majenang ini menyadari bahwa mereka adalah warga pendatang yang perlu belajar dari budaya masyarakat setempat. Oleh karena itu menjadi hal yang sangat penting untuk mempelajari karakter masyarakat Majenang, khususnya masyarakat yang tinggal di daerah pegunungan. Melalui identifikasi yang dilakukan ini, dapat dijadikan pedoman bagi dokter-dokter dalam bertindak untuk mengedukasi pasien yang masih memiliki pemahaman serta persepsi yang salah terhadap proses penyembuhan. Mengacu dari pendapat Rogers (dalam Cangara, 2014:64), strategi komunikasi merupakan suatu rancangan yang dibuat untuk mengubah tingkah laku manusia dalam skala yang lebih besar melalui transfer ide-ide baru.

Sosialisasi ke desa-desa. Strategi ketiga yang dilakukan dokter untuk menghadapi hambatan terkait dengan budaya, khususnya kepercayaan masyarakat yang masih lebih percaya ke dukun adalah dengan melakukan sosialisasi ke desa-desa tentang pentingnya penanganan medis ketika sakit. Terkait hal ini, dokter Dh mengatakan,

"Untuk hal itu kita biasanya bikin sosialisasi ke desa-desa, disana kita menjelaskan bahayanya patah tulang kalau langsung dipijat oleh dukun akibat paling fatalnya itu bisa lumpuh total atau amputasi, disana juga kita memutarkan video tentang contoh orang-orang yang diamputasi akibat salah penanganan supaya mereka tau”.

Upaya yang sama juga dilakukan oleh dokter Art. Dalam wawancara mendalam pada tanggal 22 Januari 2020 beliau mengatakan,

"Biasanya kami sosialisasi ke masyarakat desa yang di gunung-gunung, biasanya tentang bahaya dan akibat apabila salah penanganan, dan pentingnya harus ada penanganan medis". 


\section{KESIMPULAN}

Sebagai Rumah Sakit yang terletak di wilayah perbatasan Jawa Tengah dan Jawa Barat, membuat RSU Raffa menjadi tempat bertemunya keanekaragaman budaya dalam dunia medis. Komunikasi yang terjalin antara dokter dan pasien menggunakan komunikasi verbal dan non-verbal. Komunikasi verbal yang digunakan yaitu dengan mengucapkan salam, menanyakan kondisi pasien, menanyakan apa saja aktifitas pasien di rumah. Dalam melakukan proses pelayanan kesehatan para dokter menggunakan Bahasa Indonesia dan pasien menggunakan Bahasa Jawa Ngapak. Komunikasi non verbal yang terdapat dalam proses komunikasi dokter dan pasien di RSU Raffa yaitu senyuman (mimik wajah), gerakan-gerakan tubuh (gesture), dan melakukan sentuhan-sentuhan fisik seperti menyentuh dahi pasien dan memberikan tepukan pada pundak pasien. Ada beberapa hambatan yang terjadi dalam komunikasi antarbudaya antara dokter dan pasien, hambatan tersebut adalah hambatan Budaya (cultural), hambatan Bahasa (linguistic) dan hambatan Persepsi (motivational), yaitu perbedaan persepsi dalam memahami proses penyembuhan penyakit dan kepercayaan masyarakat yang masih mempercayai dukun.

Untuk mengatasi hambatan-hambatan yang terjadi, ada empat strategi yang digunakan oleh paramedis yang ada di RSU Raffa. Strategi tersebut adalah Strategi dengan menggunakan penerjemah, edukasi pasien, mempelajari budaya dan karakter pasien dan Sosialisasi ke desa-desa. Strategi-strategi ini digunakan oleh dokter dalam melakukan proses pelayanan kesehatan, yaitu menggunakan penterjemah atau translator untuk memudahkan komunikasi, memberikan pemahaman ketika dokter visit. Pada saat visit, dokter menjelaskan tentang rentang waktu proses pemulihan pasien. Selain itu, dokter juga mempelajari budaya dan karakter masyarakat setempat demi kelancaran proses komunikasi dengan bertanya melalui dokter atau perawat yang merupakan penduduk asli Majenang. Dalam tindakannya, dokter juga belajar bahasa Jawa Ngapak dan mulai menerapkannya ketika sedang berkomunikasi dengan pasien. Dan strategi yang terakhir yaitu mengadakan sosialisasi di desa-desa terutama yang berada di gunung dengan tujuan untuk memberikan pemahaman terkait pentingnya penanganan medis agar masyarakat tidak salah paham dan tidak sembarangan dalam melakukan tindakan medis.

\section{DAFTAR PUSTAKA}

Samovar, Larry A. \& Richard E. Porter. (1994). Intercultural Communication: A Reader. Ten ${ }^{\text {th }}$ Edition. Australia: Wadsworth.
Samovar, Larry A; Richard E Porter and Edwin R McDaniel. 2012. Intercultural Communication: $A$ Reader. $13^{\text {th }}$ edition. United States: Wadsworth Cengage learning.

Aw, S. (2010). Komunikasi Sosial Budaya. Yogyakarta: Graha Ilmu.

Cangara, H. (2014). Perencanaan Strategi Komunikasi (Ed Revisi). Jakarta: PT RajaGrafindo Persada.

Chaney, Lilian, Martin, Jeanette, \& Martin. (2004). Intercultural Business Communication. New Jersey: Pearson Education, Inc, Upper Saddle River.

Darmastuti, R. (2013). Mindfullness Dalam Komunikasi Antarbudaya (Mapa, Ed.). Yogyakarta: Buku Litera Yogyakarta.

Devito, J. A. (1997). Komunikasi Antarmanusia: Kuliah Dasar. Jakarta: Professional Books.

Effendy, O. U. (2004a). Dimensi-dimensi Komunikasi (Cet. Ke-4). Bandung: PT. Remaja Rosdakarya.

Effendy, O. U. (2004b). Dinamika Komunikasi. Bandung: PT Remaja Rosdakarya.

Effendy, O. U. (2011). Ilmu Komunikasi Teori dan Praktek. Bandung: PT. Remaja Rosdakarya.

Fauziah, S. (2015). Faktor Sosiokultural dalam Pemakaian Bahasa. Zawiyah Jurnal Pemikiran Islam, l(1), 154-174.

Fitrah, M. dan L. (2017). Metodologi Penelitian; Penelitian Kualitatif, Tindakan Kelas \& Studi Kasus). Sukabumi: CV Jejak.

Griffin, E. A. (2003). A First Look at Communication Theory. New York City: McGraw-Hill.

Hadi, F. (2017). Komunikasi Antarbudaya pada Mahasiswa Bangka-Sunda (Studi Etnografi Komunikasi Kedwibahasaan Pada Mahasiswa Bangka-Sunda di FISIP UNPAS Bandung). PERPUSTAKAAN.

Jandt, F. E. (1998). Intercultural Communication, An Introduction. London: Sage Publication.

Keraf, \& Gorys. (1997). Komposisi: Sebuah Pengantar Kemahiran Bahasa. Ende: Nusa Indah.

Liliweri, A. (2003). Dasar-dasar Komunikasi Antarbudaya. Yogyakarta: Pustaka Pelajar.

Liliweri, A. (2011). Komunikasi Serba Ada Serba Makna. Jakarta: Kencana Prenada Media Group.

Littlejohn, W. S. (2012). Teori Komunikasi. Jakarta: Salemba Humanika.

Pemerintah Kabupaten Cilacap. (n.d.). Profil Kondisi Geografis Kabupaten Cilacap.

Putri, M. H. (2014). Strategi Komunikasi Antarbudaya dalam Mengurangi Stereotipe Negatif Terhadap Suku Batak di Rusunawa Keudah, Banda Aceh. Universitas Syiah Kuala.

Rakhmat, J. (2007). Persepsi Dalam Proses Belajar Mengajar. Jakarta: Rajawali Pers. 
Regar, P. P., Kawung, E., \& Tangkudung, J. P. M. (2014). Pola komunikasi antar budaya dan identitas etnik Sangihe - Talaud - Sitaro (Studi pada Masyarakat Etnik Sanger-Tahuna-Sitaro di Kota Manado). Journal Acta Diurna, III, 1-10.

Ridwan, A. (2016). Komunikasi Antarbudaya (Mengubah Persepsi dan Sikap dalam Meningkatkan Kreativitas Manusia). Bandung: CV Pustaka Setia.

Samovar, Larry A., R. E. P., \& McDaniel, dan E. R. (2010). Komunikasi Lintas Budaya (Communication Between Cultures) (7th ed.). Jakarta: Salemba Humanika.

Samovar, L. A., Porter, R. E., \& McDaniel, E. R. (2012). Intercultural Communication A Reader (13th editi). USA: Wadsworth Cengage Learning.

Simanjuntak, D. R. (2016). Pelayanan Kesehatan dalam pendekatan komunikasi antarbudaya (Studi fenomenologi pelayanan kesehatan Dokter kepada Pasien di RSUP H. Adam Malik Medan). Jurnal Simbolika.

Soeprapto, R. (2002). Interaksi Simbolik, Perspektif Sosiologi Modern. Yogyakarta: Averrpes Press dan Pustaka Pelajar.

Soesilo. (2004). Kejawen: Philosofi \& Perilaku. Jakarta: Yayasan "Yusula."
Spradley, J. (1997). Metode Etnografi (M. Z. Elizabeth \& Tiara Wacana, Eds.). Yogyakarta.

Subandi, A. (1982). Psikolog Sosial (cet. ke-11). Jakarta: Bulan Bintang.

Sugiyono. (2005). Memahami Penelitian Kualitatif. Bandung: CV, Alberta.

Sugiyono. (2007). Metode Penelitian Pendidikan. Bandung: Alfabeta.

Sugiyono. (2012). Metode Penelitian Kuantitatif dan $R \& D$. Bandung: Alfabeta.

Tubbs, S., \& Moss, S. (2008). Human Communication Principles and Contexts (8th ed). Boston: McGraw-Hill.

Turnomo, R. (2005). Menghargai Perbedaan Kultural: Mindfulness dalam Komunikasi Antaretnis.

Venus, A., Syafirah, N. A. Salam, N. E. (2019). Stereotip, Melayu, Etnik, Reformasi, Pendatang. Jurnal Manajemen Komunikasi, 3(2), 131-141.

Warsito. (2012). Antropologi Budaya. Yogyakarta: Penerbit Ombak.

Widyastuti, D. A. R., Birowo, M. A., \& Sidhi, T. A. P. (2019). Konsep Diri Perempuan Di Kawasan Rawan Bencana Gunung Merapi. Jurnal ASPIKOM, 4(1), 156. https://doi.org/10.24329/ aspikom.v4i1.420 